\title{
DESAIN MODEL PEMBELAJARAN GERLACH DAN ELY YANG BERCIRI NILAI-NILAI KE-ISLAMAN UNTUK MENINGKATKAN KEMAMPUAN KOMUNIKASI MATEMATIS
}

\author{
Reza Setiawati $^{1}$, Netriwati ${ }^{2}$, Sri Purwanti Nasution ${ }^{3}$ \\ 1,2,3 Pendidikan Matematika, Universitas Islam Negeri Raden Intan Lampung \\ E-mail: reza.setiawati209@gmail.com ${ }^{1)}$, \\ netriwati@ radenintan.ac.id ${ }^{2}$, \\ sripurwanti@yahoo.co.id ${ }^{3)}$
}

Received 24 October 2018, Received in revised form 28 November 2018; Accepted 26 December 2018

\begin{abstract}
The low mathematical communication skills in SMA 2 Natar, South Lampung, are caused by various factors, including the assumption that mathematics is very difficult so students still tend to be passive. The purpose of this study was to determine the mathematical communication skills of students who used the Gerlach and Ely learning models that characterized Islamic values better than conventional learning. The population in this study were students of class X Natar 2 Public High School. This research is a preexperimental design with one-group pretest-posttest type. The test prerequisite analysis was done by Liliefors test for normality and F test for homogeneity, then the data were analyzed using N-Gain test and correlated t-test. The results of the analysis in the t-test test correlates mathematical communication skills in the material of the nilier equation system three variables at the significance level $\alpha=0.05$ obtained by tcount $=24.19$ Ttable $=2.045$ 24, Thitung $>$ T table so that in the calculation of HO is rejected. Similarly, mathematical communication skills can be improved after using the Gerlach and Ely learning model characterized by Islamic values on the subject of the three-variable linear equation system.
\end{abstract}

Keywords: Gerlach and Ely Model; Islamic values; mathematical communication

\section{PENDAHULUAN}

Pendidikan adalah proses pengembangan potensi seseorang untuk mencapai kematangan diri (wawasan). (Musfah, 2016). Maka dari itu perlu pendidikan yang mengajarkan nilainilai dan dapat membentuk kepribadian yang berkarakter, berahlak mulia dan beradap yaitu pendidikan Islam (Sudiyono, 2009). Dengan demikian tujuan pendidikan merupakan salah satu hal yang penting dalam kegiatan pendidikan, karena akan memberikan arah kemana harus menuju, tetapi juga memberikan ketentuan yang pasti dalam memilih materi (isi), metode, alat evaluasi dalam kegiatan yang dilakukan. Secara umum tujuan pendidikan dapat dikatakan membawa anak kearah tingkat kedewasaan (Suryosubroto, 2010). Nilai-nilai Islam berciri dalam proses pembelajaran khususnya pembelajaran matematika. Pembelajaran matematika adalah proses terhubungnya antara pendidik dan peserta didik atas dasar hubungan timbal balik yang berlangsung dalam keadaan edukatif untuk mencapai tujuan tertentu. Sehingga dapat mengantarkan peserta didik akan mencapai pengetahuan (kognitif), pemahaman dan penerapan nilai-nilai ke-Islaman.

Salah satu alasannya mengapa demikian adalah karena matematika merupakan ilmu yang dalam proses pembelajarannya saling berkaitan antara materi awal dan materi selanjutnya, peserta didik cenderung sulit memahami materi baru apabila dalam materi sebelumnya peserta didik tidak memahaminya (Sabirin, 2014) 
$\begin{array}{clr}\text { Dengan } & \text { kata lain, melalui } \\ \text { pembelajaran } & \text { matematika dapat }\end{array}$ ditanamkan nilai-nilai religius pada anak (Diana, dkk 2018). Oleh sebab itu diperlukan suatu pembelajaran matematika yang berciri nilai-nilai Islam pada sela-sela proses pembelajaran. Namun diera kemajuan ilmu pengetahun teknologi seperti ini, seharusnya kesadaran para pendidik bahwa menuntut para pendidik untuk lebih kreatif dan inovatif dalam menyampaikan pembelajaran sehingga peserta didik bisa belajar mandiri. Dengan mendesain model pembelajaran yang berciri dengan nilainilai ke-Islaman dapat merangsang peserta didik untuk dapat meningkatkan kemampuan komunikasi dan menghubungkan topik-topik matematika yang disajikan dengan pristiwa, kejadian, masalah yang dihadapi dalam kehidupan sehari-hari khususnya dalam penerapan praktek ibadah yang dijalankan. Salah satunya dengan meningkatkan kemampuan komunikasi matematis peserta didik.

Kemampuan komunikasi adalah bagian terpenting dari kehidupan karena dengan komunikasi anak dapat mengekspersikan perasaan dan mengungkapkan ide serta pemikirannya. Dengan demikian, kemampuan komunikasi matematis diperlukan peserta didik untuk menemukan dan membuat suatu alat atau cara berfikir dalam mengkomunikasikan gagasan matematis dari yang sifatnya abstrak menuju konkret, sehingga lebih mudah dipahami. Tetapi pada kenyataanya kemampuan komunikasi matematis masih kurang, sehingga masih banyak peserta didik yang kesulitan dalam belajar matematika.

$$
\text { Selanjutnya }
$$

rendahnya

kemampuan komunikasi matematis, minimnya pengetahuan pendidik terhadap berbagai model pembelajaran juga sangat berpengaruh dalam proses pembelajaran dan mengakibatkan kurang tepatnya model pembelajaran yang digunakan. Serta rendahnya kemampuan siswa dalam memahami soal cerita matematika. Siti Khayroyah, dkk (2018). peserta didik cenderung merasa bosan karena terjadi komunikasi satu arah yang memberikan sedikit kesempatan kepada peserta didik untuk berfikir matematis dan berdiskusi dengan peserta didik lain, sehingga hanya sedikit bentuk komunikasi matematis yang diketahui dan dikuasai peserta didik (Darkasyi, 2014). Hal ini disebabkan banyak faktor, misalnya rendahnya tingkat belajar siswa untuk mempelajari matematika, bisa juga dikarenakan materinya yang dianggap sulit bahkan dari bahan ajarnya yang membuat sulit siswa. Rizki dan Linuhung (2016).

Sejalan dengan permasalahan di atas, diperlukan suatu alternatif model pembelajaran yang membuat peserta didik menjadi aktif dan membuat suasana pembelajaran yang menyenangkan, sehingga peserta didik tidak merasa bosan dalam kegiatan belajar mengajar (KBM), serta model pembelajaran yang cocok untuk meningkatkan kemampuan komunikasi matematis peserta didik. Kemampuan komunikasi peserta didik secara lamgsung dalam proses membaca, berpikir, berdialog, berbicara, membagi ide (sharing) serta mengembangkan tulisan dengan lancar. Dalam setiap tahapan proses pembelajaran diperlukan suatu model pembelajaran yang mampu mendorong peserta didik untuk mengembangkan proses berpikir dalam meningkatkan ide-ide kreatif peserta didik. Hal ini tentunya tidak terlepas dari peran pendidik yang menjadi monitoring dan menilai partisipasi peserta didik sehingga

\section{2 | AKSIOMA}

Jurnal Pendidikan Matematika FKIP Univ. Muhammadiyah Metro 
pendidik harus dapat menggunakan model pembelajaran yang tepat supaya berjalan sesuai skenario yang diharapkan. Salah satu alternatifnya adalah model pembelajaran Gerlach dan Ely.

Model pembelajaran Gerlach dan Ely sesuatu cara yang sisitematis dalam mengidentifikasi, mengembangkan, dan mengevaluasi seperangkat materi dan strategi yang diarahkan untuk mencapai tujuan pendidik tertentu. Model pmebelajaran Gerlach dan Ely bermanfaat sebagai pedoman atau suatu peta perjalanan dalam membuat suatu rencana proses belajar mengajar yang baik sehingga dapat meningkatkan cara berfikir peserta didik (Sitorus, 2017). Dengan demikian maka dapat berpengaruh dalam meningkatkan kemampuan komunikasi matematis peserta didik. Selain menggunakan model pembelajaran yang tepat, peneliti juga melakukan desain model pembelajaran yang berciri nilai-nilai ke-Islaman karena akan menjadi sampel pada penelitan ini adalah sekolah menengah atas yang berciri ke-Islaman.

Penelitian yang relevan dengan penelitian ini yaitu berdasarkan penelitian yang dilakukan oleh Handayani, dkk (2016) bahwa kemampuan komunikasi siswa masih rendah. Karena belum menggunakan model pembelajaran yang tepat. Sehingga menyebabkan tidak mampu mendefinisikan kembali dengan menggunakan bahasa mereka sendiri. Berdasarkan penelitian yang dilakukan oleh Yusnita, dkk (2016). kemampuan komunikasi matematisnya masih rendah. hal ini karena guru kurang memberikan kebebasan siswa untuk dapat mengekspresikan pendapatnya. Penelitian Sitorus, dkk (2017) bahwa kemampuan komunikasi matematis siswa meningkat setelah menggunakan model pembelajaran Gerlach dan Ely lebih baik, dan diharapkan untuk menerapkan model pembelajaran Gerlach dan Ely sebagai salah satu alternatif untuk mencapai tujuan pembelajaran.

Tujuan dalam penelitian ini adalah untuk mengetahui apakah desain model pembelajaran Gerlach dan Ely yang berciri nilai-nilai ke-Islaman untuk meningkatkan kemampuan komunikasi matematis.

\section{METODE PENELITIAN}

Jenis penelitian ini adalah preexperimental dengan desain one-grup pretest- posttest dimana membandingkan nilai tes awal (pretest) dan nilai tes akhir (postest) untuk melihat kemampuan akhir peserta didik. Terdapat dua variabel dalam penelitian ini yaitu variabel bebas dan variabel terikat, yang menjadi variabel bebasnya adalah model pembelajaran gerlach dan ely yang bericiri nilai-nilai ke-Islaman yang dilambangkan $(\mathrm{X})$ dan yang menjadi variabel terikatnya adalah kemampuan komunikasi matematis dengan lambang (Y) (Creswell, 2013).

Populasi yang digunakan dalam penelitian ini adalah peserta didik kelas $X$ SMA Negeri 2 Natar. Adapun sampel pada penelitian ini adalah peserta didik kelas $\mathrm{X}$ IIS 3 yang berjumlah 30 peserta didik.

Instrumen yang diguankan dalam penelitian ini berbentuk tes. Tes kemampuan komunikasi matematis yang digunakan dalam penelitian ini adalah tes uraian. Ketentuan dalam tes ini adalah setiap jawaban benar semua diberi skor 4 dan jawaban salah diberi skor 0 atau kata lain skor dalam interval (0-4) sehingga diperoleh skor mentah, kemudian skor tesebut ditranformasikan menjadi skala 0 sampai dengan 100. 
Instrumen penelitian ini adalah instrumen tes berupa tes bentuk uraian untuk mengukur kemampuan komunikasi matematis peserta didik. Sebelum dilakukan uji coba instrumen, maka soal yang akan diberikan harus di uji validitasnya, untuk melihat bahwa tes itu berdasarkan isinya valid, seseorang harus melihat bahwa instrumen yang akan diujikan, sesuai dengan standar kopetensi, kopetensi dasar, kurikulum, dan sesui dengan tujuan pembelajaran yang ingin dicapai. Dalam hal ini melibatkan pihak yang berkopeten untuk memeriksa validitasnya yakni pembimbing, dosen pendidikan matematika, dan guru pelajaran matematika.

Setelah melakukan uji coba instrumen sebelum instrumen diberikan kepada sampel dilakukan uji validitas soal, uji tingkat kesukaran, uji daya pembeda soal dan uji reliabilitas soal untuk mengetahui baik atau tidaknya instrumen yang akan digunakan. Pengujian prasyarat analisis dilakukan dengan uji liliefors untuk normalitas uji $F$ untuk homogenitas (Novalia, 2014). Selanjutnya analisis data dalam penelitian ini menggunakan uji-t berkorelasi untuk menguji hipotesis dan uji N-Gain untuk mengetahui peningkatan kemampuan komunikasi matematis.

\section{HASIL PENELITIAN DAN \\ PEMBAHASAN}

Berdasarkan hasil analisis data

diperoleh data-data sebagai berikut:

Tabel 1. Deskripsi Data Hasil Pretest dan Posttest kemampuan komunikasi matematis

\begin{tabular}{ccccccccc}
\hline \multirow{2}{*}{ Kelompok } & \multirow{2}{*}{$\boldsymbol{X}_{\boldsymbol{m a x}}$} & $\boldsymbol{X}_{\boldsymbol{m i n}}$ & \multicolumn{3}{c}{$\begin{array}{c}\text { Ukuran Tendensi } \\
\text { Sentral }\end{array}$} & \multicolumn{2}{c}{ Ukuran Variansi Kelompok } \\
\cline { 4 - 8 } & & & $\overline{\boldsymbol{x}}$ & $\boldsymbol{M}_{\mathbf{0}}$ & $\boldsymbol{M}_{\boldsymbol{e}}$ & $\boldsymbol{R}$ & $\boldsymbol{S}$ \\
\hline Pretest & 60 & 15 & 39,833 & 50 & 40 & 45 & 10,786 \\
posttest & 95 & 65 & 84,5 & 95 & 85 & 30 & 9,224 \\
\hline
\end{tabular}

Berdasarkan hasil Tabel 1, hasil test sebelum proses pembelajaran (pretest) diperoleh nilai rata-rata $(\bar{x})$ 39,833, median $\left(M_{0}\right)$ 50, modus $\left(\mathrm{M}_{\mathrm{e}}\right)$ 40, rentang (R) 45, Simpangan baku (S) 10,786. Nilai tertinggi $\left(\mathrm{X}_{\text {maks }}\right) 60$ dan nilai terendah $\left(\mathrm{M}_{\min }\right) 15$. Perhitungan data setelah proses pembelajaran

(posttest) menggambarkan bahwa dari 30 peserta didik diperoleh nilai rata-rata $(\bar{x}) 84,5$. median $\left(M_{0}\right)$ 95, modus $\left(\mathrm{M}_{\mathrm{e}}\right)$ 85, rentang $(\mathrm{R})$ 30, Simpangan baku (S) 9,224. tertinggi $\left(X_{\text {maks }}\right) 95$ dan nilai terendah $\left(\mathrm{M}_{\min }\right) 65$.

Tabel 2. Hasil Uji Normalitas Data Kemampuan Komunikasi Matematis

\begin{tabular}{cccccc}
\hline No & Perlakuan & $\mathbf{N}$ & $\mathbf{L}_{\text {hitung }}$ & $\mathbf{L}_{\text {tabel }}$ & Keputusan Uji \\
\hline 1 & Pretest & 30 & 0,061 & 0,158 & $\mathrm{H}_{\mathrm{O}}$ Diterima (Normal) \\
2 & postest & 30 & 0,148 & 0,151 & $\mathrm{H}_{\mathrm{O}}$ Diterima (Normal) \\
\hline
\end{tabular}

\section{4 | AKSIOMA}


Berdasarkan keterangan Tabel 2, dari uji normalitas data amatan hasil tes kemampuan komunikasi matematis, tampak bahwa nilai $\mathrm{L}_{\text {tabel }}$ ( $\mathrm{L}_{\text {hitung }}<$ $\left.\mathrm{L}_{\text {tabel }}\right)$. Hal ini berarti pada taraf signifikasi $\alpha=0,05 . \mathrm{H}_{0}$ untuk setiap kelompok diterima. Dengan demikian data pada setiap perlakuan pretest dan postest berasal dari data yang berdistribusi normal.

Berdasarkan hasil perhitungan uji homogenitas Kesimpulannya yaitu $\mathrm{F}_{\text {hitung }} \leq \mathrm{F}_{\text {tabel }}$ maka hasil uji $\mathrm{H}_{0}$ diterima artinya data berasal dari varians yang sama.

Tabel 3. Hasil perhitungan uji $N$-Gain Kemampuan Komunikasi Matematis

\begin{tabular}{ccccc}
\hline & Pretest & Postest & N-Gain & Kriteria \\
\hline$\Sigma$ & 1195 & 2535 & & \\
$\bar{x}$ & 39,833 & 84,5 & 0,809 & Tinggi \\
\hline
\end{tabular}

Berdasarkan data yang diperoleh pada Tabel 3, maka hasil perhitungan menunjukan adanya kriteria-kriteria sesuai nilai-nilai yang dicapai, dengan perolehan nilai pretest 15 dan postest 65 memproleh kriteria rendah, adapun salah satu yang memperoleh kririteria tinggi dengan perolehan nilai pretest 65 dan postest 95 dengan nilai N-Gain 1. berdasarkan hasil yang diperoleh pada tabel 3, maka N-Gain secara keseluruhan adalah 0,809 . Perhitungan N-Gain ternormalisasi secara keseluruhan berdasarkan kriteria memperoleh kriteria tinggi.

Tabel 4. Hasil perhitungan uji $t$-test berkorelasi

\begin{tabular}{cc}
\hline Diperoleh & Pretest dan Posttest \\
\hline $\mathrm{T}_{\text {hitung }}$ & 24,19 \\
$\mathrm{~T}_{\text {tabel }}$ & 2,045 \\
\hline
\end{tabular}

Perhitungan menunjukan $\left|t_{\text {hitung }}\right|>$ $\mathrm{t}_{\text {tabel }}$, maka $\mathrm{H}_{0}$ ditolak $\mathrm{H}_{1}$ diterima. Kesimpulan dari uji-t berkorelasi Perhitungan menunjukan $\left|t_{\text {hitung }}\right|>$ $\mathrm{t}_{\text {tabel }}$ yaitu $=24,193>2,045$ sehingga dalam perhitungan $\mathrm{H}_{0}$ ditolak artinya $\mathrm{H}_{1}$ diterima yaitu: kemampuan komunikasi matematis 'peserta didik meningkat setelah menggunakan desain model pembelajaran Gerlach dan Ely yang berciri nilai-nilai ke-Islaman dibandingkan kemampuan komunikasi matematis peserta didik sebelum menggunakan desain model pembelajaran Gerlach dan Ely yang berciri nilai-nilai ke-Islaman.
Desain model pembelajaran Gerlach dan Ely yang berciri nilai-nilai ke-Islaman dapat menjadikan peserta didik lebih aktif, mudah memahami materi, dan memotivasi peserta didik untuk ikut serta berpartisipasi dalam proses pembelajaran. Dalam pembelajaran model pembelajaran Gerlach dan Ely terdapat sepuluh tahapan dalam proses pembelajaran yaitu merumuskan tujuan pembelajaran (spesificstion of object), menentukan isi materi ( spesification of content), penilaian kemampuan awal peserta didik (assesement of entering behaviors), menentukan strategi (determination of strategy), 
pengelompokan belajar (organization of groups), menentukan pembagian waktu (allocation of times), menentukan ruang (allocation of space), memilih media instruksional yang sesuai (allocation of resources), mengevaluasi hasil belajar ( evalution of perfomance), dan menganalisis umpan balik (analisys of feedback) (Rusman, 2013).

Desain model pembelajaran yang berciri nilai-nilai ke-Islaman berada pada penentuan strategi dan memilih media instruksional yang akan digunakan dalam proses pembelajaran, strategi dan media yang digunakan merupakan keteladanan, ibrah dengan cerita, ceramah dan mau'zah (nasehat), tanya jawab, perumpamaan dan sindiran, demonstrasi, pembiasaan, pengalaman langsung, dan penugasan, serta penggunaan alat-alat dan media pembelajaran berupa wacana Islami, gambar-gambar atau potret-potret Islami dan praktek ibadah yang sesuai dengan kehidupan nyata.

Pertemuan pertama, guru memberikan soal pretest kepada peserta didik untuk mengetahui kemampuan awal siswa. pada pertemuan selanjutnya peserta didik diberi kan pembelajaran dengan menggukan desain model pembelajaran Gerlach dan Ely yang berciri nilai-nilai ke-Islaman. Desain model pembelajaran Gerlach dan Ely yang berciri nilai-nilai ke-Islaman terlebih dahulu pendidik menyampaikan tujuan pembelajaran atau target yang ingin dicapai dalam kegiatan pembelajaran, pendidik menentukan pokok bahasan yang lebih spesifik agar apa yang akan diberikan lebih jelas dan mudah dipahami peserta didik serta sesuai dengan tujuan yang ingin dicapai, pendidik melaksanakan penilaian kemampuan awal (pretest) pada materi yang akan diberikan agar dapat memberikan dosis pembelajaran yang tepat. Dalam proses pembelajaran peserta didik juga dibagi menjadi kelompok-kelompok kecil dimana satu kelompok maksimal terdiri dari 5 orang peserta didik. Setiap kelompok diberi suatu masalah yang harus dipecahkan, peserta didik diberi kesempatan untuk menuangkan ide-ide kreatifnya dalam menjawab masalah dengan caranya sendiri, jadi peserta didik diberi kebebasan untuk menyampaikan pemikirannya dalam menyelesaikan masalah yang diberikan dan peserta didik harus lebih aktif dari pada pendidik. Saat diskusi pendidik berlaku sebagai pembimbing, fasilitator dan motivator yang hanya mengarahkan peserta didik. Pada tahap elaborasi pendidik memilih peserta didik secara acak dari masing-masing kelompok yang akan mempresentasikan kerja kelompoknya sementara peserta didik yang lain memperhatikan, menanggapi ataupun memberikan pertanyaan. Pada pertemuan pertama, materi pembelajaran adalah mendesain menyelesaikan sistem persamaan linier tiga variabel dengan menggunakan metode eliminasi dengan soal cerita yang diberikan pendidik yang sudah didesain dengan nilai-nilai ke-islaman.

Selanjutnya pada pertemuan kedua dengan materi menyelesaikan soal dengan menggunakan cara substitusi. Media yang digunakan ini benda-benda nyata didalam kelas seperti meja, papan tulis dan bendabenda nyata yang dimisalkan dalam soal, pada pertemuan kedua hanya terletak pada waktu, karena dalam kelompok presentasi menjelaskan secara rinci dan terlalu banya pertanyaan dari kelompok lain sehingga tidak semua kelompok dapat maju kedepan kelas untuk mempresentasikan hasil yang telah di kerjakan. Kemudian pendidik 
membatasi waktu untuk setiap kelompok mempresentasikan hasil tugas kelompoknya.

Pada pertemuan ketiga dengan materi sistem persamaan linier tiga variabel dengan menggunakan cara gambungan antara eliminasi dan substitusi, pada pertemuan ketiga ini, pembelajaran dengan baik dan tidak ada kendala ketika proses pembelajaran berlangsung. Peserta didik mempresentasikan jawaban dari soal yang telah diselesaikan secara berkelompok, peserta didik perwakilan dari setiap kelompoknya secara bergantian menjelaskan dengan cara masing-masing untuk mengetahui cara penyelesaian soal tersebut.

Secara keseluruhan pembelajaran dengan mendesain model pembelajaran Gerlach dan Ely yang berciri nilai-nilai ke-Islaman berjalan dengan baik. Dapat dilihat pada lampiran-lampiran bahwa adanya peningkatan kemampuan komunikasi matematis peserta didik setelah menggunakan desain model pembelajaran Gerlach dan Ely yang berciri nilai-nilai ke-Islaman. Adapun terlihat bahwa rata-rata kemampuan komunikasi matematis peserta didik lebih dari rata-rata kemampuan komunikasi matematis peserta didik sebelum menggunakan desain model pembelajaran Gerlach dan Ely yang berciri nilai-nilai ke-Islaman dapat meningkat kemampuan komunikasi matematis karena dapat memudahkan proses pembelajaran peserta didik dalam memahami materi sistem persamaan linier tiga variabel.

Uji prasayarat telah terpenuhi sehingga dilanjutkan pada uji hipotesis dengan uji gain ternormalisasi dan uji- $t$ berkorelasi. Berdasarkan perhitungan $N$-gain secara rata-rata dengan tujuan untuk melihat apakah terdapat peningkatan kemampuan komunikasi matematis peserta didik. Dari hasil data analisis yang telah dilakukan bahwa dengan menggunakan desain model pembelajaran Gerlach dan Ely yang berciri nilai-nilai ke-Islaman peserta didik memiliki peningkatan kemampuan komunikasi matematis. Pad uji $\mathrm{N}$-gain terletak kriteria yang diperoleh secara keseluruhan adalah kriteria tinggi, dimana hasil postest lebih tinggi dibandingkan hasil pretest.

Uji prasyarat selanjutnya adaah uji t-test bekorelasi, berdasarkan analisis data diperoleh bahwa terdapat peningkatan kemampuan komunikasi matematis peserta didik setelah diberikan pembelajaran menggunakan desain model pembelajaran Gerlach dan Ely yang berciri nilai-nilai keIslaman.

keseluruhan kemampuan komunikasi matematis peserta didik setelah diberikan pembelajaran dengan desain model pembelajaran Gerlach dan Ely yang berciri nilai-nilai keIslaman memiliki peningkatan yang signifikan dari hasil belajar siswa pada pelajaran matematika dibandingkan dengan kemampuan komunikasi matematis peserta didik sebelum diberikan pembelajaran dengan desain model pembelajaran Gerlach dan Ely yang berciri nilai-nilai ke-Islaman.

Penelitian ini sejalan dengan penelitian yusnita, dkk (2016) bahwa dengan menggunakan model pembelajaran Gerlach dan Ely dapat meningkatkan minat belajar siswa pada saat proses pembelajaran.

\section{KESIMPULAN DAN SARAN}

Berdasarkan hasil penelitian dan analisis maka dapat disimpulkan bahwa: desain model pembelajaran Gerlach dan Ely yang berciri nilainilai ke-Islaman dapat meningkatkan kemampuan komunikasi matematis. 
Saran dapat diberikan kepada
guru yang menggunakan model pembelejaran Gerlach dan Ely sebagai model alternatif dalam mencapai tujuan pembelajaran. disarankan bagi penelitian selanjutnya dapat menerapkan dan mengembangkan model Gerlach dan Ely. Dengan memberikan pujian, reward sehingga dapat meningkatkan kualitas pembelajaran dan meningkatkan kemampuan komunikasi matematis siswa.

\section{DAFTAR PUSTAKA}

Creswell, J. W. (2013). Research Design, Pendekatan Metode Kualitatif, Kuantitatif, Dan Campuran . Yogyakarta: Pustaka Pelajar.

Darkasyi, M., Johar, R., \& Ahmad, A. (2014). Peningkatan Kemampuan Komunikasi Matematis Dan Motivasi Siswa Dengan Pembelajaran Pendekatakan Quantum Learning Pada Siswa Smp Negeri 5 Lhokseumawe. Didaktik Matematika , ISSN: 2355-4185. hal. 21-34.

Diana, M., Netriwati, \& Suri, F. I. (2018). Modul Pembelajaran Matematika Bernuansa Islami Dengan Pendekatan Inkuiri. Desimal: Jurnal Matematika , Vol 1 No 1. hal. 7-13.

Handayani, A., Mukhni, \& Za, N. (2014). Analisis Kemampuan Komunikasi Matematis Siswa Melalui Pendekatakan Pendidikan Matematika Realistik (PMR) Siswa Kelas VII MTs Negeri Lubuk Buaya Padang Tahun Pelajaran 2013/2014. Jurnal Pendidikan Matematika , Vol 3 No 2. hal. 1-6.
Khayroyah, S., \& Ramhadani. (2018). Peningkatan Kemampuan Pemecahan Masalah Pada Soal Cerita Matematika Menggunakan Model Pbl Berbasis Media Realistik. Jurnal Matheducation Nusantara, Vol 1 No 2. hal. 1217.

Musfah, J. (2016). Redesin Pendidikan Guru. Jakarta: Kencana.

Novalia, \& Syazali. (2014). Olah Data Penelitian Pendidikan. Bandar Lampung: Anugrah Utama Raharja.

Rizki, S., \& Linuhung, N. (2016). Pengembangan Bahan Ajar Program Linier Berbasis Konstektual Dan Ict . Pendidikan Matematika Fkip Universitas Muhammadiyah Metro , e-ISSN 2442-5419 Vol 2, No 2. hal. 137144.

Rusman. (2013). Model-Model Pembelajaran. Jakarta: Rajawali Pers.

Sabirin, M. (2014). Representasi Dalam Pembelajaran Matematika. Jmp Iain Antasari, Vol 1 No 2. hal. 33-44.

Sitorus, E. N., \& Purba, M. M. (2017). Pengaruh Model Pembelajaran Gerlach Dan Ely Terhadap Kemampuan Komunikasi Matematis Siswa. Semnastikaunimed, ISBN: 97817980. hal. 337-342.

Sudiyono. (2009). Ilmu Pendidikan Islam. Jakarta: Pt Rineka Cipta.

Suryosubroto. (2010). Dasar-Dasar Kependidikan . Jakarta: Pt Rineka Cipta. 
ISSN 2089-8703 (Print) Vol. 7, No. 3 (2018) 371-379

ISSN 2442-5419 (Online)

Wijaya, A. (2012). Pendidikan Matematika Realistik: Suatu Alternatif Pendekatan Pembelajaran Matematika. Yogyakarta: Graha Ilmu.

Yusnita, I., Masykur, R., \& Suherman. (2016). Modifikasi Model Pmeblejaran Gerlach Dan Ely Melalui Integrasi Nilai-Nilai Keislaman Sebagai Upaya Meningkatkan Kemampuan Representasi Matematis . AlJabar: Jurnal Pendidikan Matematika, Vol 7 No 1. hal. 2938. 